鏡視下小切開 (Endoscopic Minilaparotomy) 腎移植ドナー腎摘術

\section{東京医科歯科大学大学院 尿路生殖機能学(泌尿器科)}

鈴木 理仁“成田洋平." 新井学" 兵地 信彦" 增田均" 川上理" 林哲夫”奥野哲男”石坂和博“影山幸雄”木原和徳”

【1的】腎移植ドナー腎摘術を約 5 横指の小切開創から内視鏡下 に行い、十分な長さの㽷管之ともに摘出した。【術式】腎摘位で 第12肋骨先端部に約 5 横指の腰部斜切開を加元、第12肋骨先端部 を約 $3 \mathrm{~cm}$ 切除し以下の順で行った。1) 側腹筋は切断せず分け るのみとした (ベクセル)。2）同創より内視鏡を挿入し、以後 は鏡視下に行った。3）Gerota筋膜㣪葉之大腰筋との間を剥離し、 この剥離面を上方及び下方に㧍大した。4）尿管を確保。5） Gerota筋膜を切開し，腎線維被膜を露出させこの剥離面を腎に触 れることなく全周に抎げた。6）周用組織を十分につけた尿管を 総腸篮動脈交热部より $2 \mathrm{~cm}$ 遠位まで剥離。7) 腎動静脈の剥離。 8)レシピエントの準備が整うのを待つ。9）尿管切断、腎動脈 切断、腎静脈切断し腎摘。10)腎静脈の䋖合。11）ドレー ンを留置し閉創した。【結果】左在一例ずつ経験し、手術時間は レシピエントの待ち時間考含め180分、池血量は平均 $130 \mathrm{ml}$ 。合併 症はなく、術装田より歩行・飲水が可能であった。深部の操作を 参加者全員が観察し得た。【考察】生体腎移植ドナーにおいては 可能な限り低侵襲于術が求められる。本手術は低侵襲で, 小切開 㓱よりト分な铱さの尿管を確保するこよができ, 有用な手術法と 考えられる。

ドナー腎摘 ミニラパロトミー 腹腔鏡

\section{UP-31腎癌M 1 症例で長期生存した14例の臨床検 討}

\section{防衛医大 泌尿器科}

水口 靖規" 山中優典" 植出 寻史" 住友 誠" 浅野友彦" 早川正道"

目的：術前に他臓器に転移を認め、かつ長期生存可能であった腎 細胞癌について臨林的検討を行った。対象と方法：対象は1980年 から1997华までに腎摘除された腎細胞癌224例中術前に転移を認 めかつ筒摘除後3年以上生存が可能であった14例である。年齢平 均は68.3歳（41〜82）であった。男性10例で女性4例で、観察期 間は36〜197ヶ月であった。術前の転移巣は肺のみが4例、骨のみ が4例、副婜のみが2例、骨・肝が2例、肺・肝が1例、対側腎・肺 が1例であった。主訴は血尿が5例で、嗄痛が1例、なしが6例であ つた。4例に転移巣の外科的切除が行われ、4例に腎摘除後免疫療 法が施行された。術前転移を認めかつ3年以内に死亡した腎癌 37 例之転移部位书よび病理組織学的検查所兒について比較検討を行 つた。結果：3年以上生存した群では3年以内に死亡した群に比較 して病理組織学的に異型度および進展度が低く、細胞型ではclear cell typeが多かった。有意差は鯰めなかったが肺又は骨単独の転 移怔例が肺・骨以外の臓器に転移を有した症例より予後がよい傾 问を誋めた。結論：M1粲細胞癌においても上記傾向が認められ

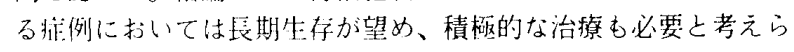
れた。

\section{腎細胞癌 遠隔転移 長期生存}

\section{UP-30 腎血管筋脂肪腫の臨床的検討 一手術症例 と非手術症例との比較検討一}

\author{
長野赤十字病院 泌尿器科"
}

天野 俊康"三輪 聰太郎”今尾哲也”竹前 克朗"

【目的】腎血管筋脂肪腫（AML）は、CTなどの画像診断の発達 に伴い小腫瘤で発見さ机症例がある一方、出晌などのため于術が 必要となる症例もある。当科で経験したAMLにつき看術症例之 非手術症例との比較を中心に検討した。【対象】画像部断または 摘除標本より病理組織学的にAML上診断された 17 例（琞：仅 =6：1 1、診断時年齢 1 6 6 2 个平诗 44.5 」藏)。【結果】 右側 4 例、左側 9 例、両側 4 例に発生し、結節性硬化症に命併し た症例は、女性の 2 例（左側、両側）であった。1 7 例中6例に、 腎摘除術が施行された。術前診断は、AMLからの出任 2 例、

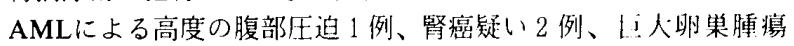
疑い1例であった。腎癌疑いの2 例は、腫痬径 $3 \mathrm{~cm}$ 以下で、術 前に鑑別が困難であった。他の4 例は腄瘍待が $11 \sim 30 \mathrm{~cm}$ 上 大きい腫瘍であった。一方、非手術の 11 例は、腫瘍待 $3 \mathrm{~cm}$ 以 下で、経過観察中に腫愓サイズの变化もほとんどなく、合併症も 認められなかった。【考察】今回の検豇では、AMLにおいて子 術を要したものは、腎癌疑いと、睡瘍径 $11 \mathrm{~cm}$ 以:で何らかの 症状を呈した症例であった。一方、腫陽栙 $3 \mathrm{~cm}$ 以下では特に症 状むなく、経過観察可能であった。以上より、AMLの腫鹪栙は 手術適応の重要な一要因であると推祭された。

腎血管筋脂肪腫 手術適応 腫瘍径

\title{
UP-32 腎細胞癌の臨床的検討
}

\section{高松赤十字病院 泌尿器科" 高松赤十字病院 病理部 2 徳島文理大学 薬学部}

中迬弘能”小泉 貴裕" 李慶寿" 小島圭.." “山本 明” 川西泰夫" 沼田 明" 荻野 哲朗" 瀬津 弘順"

【目的】当院で治療を行った腎細胞癌聇例について検婛を行っ た。【対象と方法】1983年1月から2000年5月までの17年䦌に治㙩 を行った75例を対象とし、陪床所胃（growth type、血小板数） 及び腎癌取扱い規約（1999年、3版）に基ついた病理組織学的听 見（pT、grade、組織型、静脈浸潤、INF）と予後上の関連を検 討した。【結果】性別は男性48例、女性27例で、年齢は37.81歳 (中央值61歳)であった。観察期間が5-212ヶ月（中央值77ヶ月） で全体のcause specific survival rateは5作で79\%、10年で59.7\%で あった。pT、grade、growth type、血小板数が予後規定因子てであ った。組織型、静脈浸潤、INFは一予後規定因子ではなかった。

【結論】血小板增加群の全例で遠隔転移学認め早期に癌死して いた。血小板は血管内汥增殖因子（VEGF）を移送し合成する事 で、腫瘍の增殖に関与していると京わ机ている。そこでバラフ ィン包埋切片を用いたVEGF免疫染色の片伈性、CD34充疫染色 を用いた微小血管密度 (VCM) と血小板数との相関性、予後因 子としての有用性を検討する予定である。

\section{腎細胞癌 予後因子}

